\title{
Article \\ Crystal Structure and Solid-State Conformational Analysis of Active Pharmaceutical Ingredient Venetoclax
}

\author{
Franc Perdih ${ }^{1}\left(\mathbb{D}\right.$, Nina Žigart ${ }^{2,3}$ and Zdenko Časar ${ }^{2,3, * \mathbb{D}}$ \\ 1 Faculty of Chemistry and Chemical Technology, University of Ljubljana, Večna pot 113, \\ SI-1001 Ljubljana, Slovenia; franc.perdih@fkkt.uni-lj.si \\ 2 Sandoz Development Center Slovenia, Lek Pharmaceuticals d.d, SI-1526 Ljubljana, Slovenia; \\ nina.zigart@novartis.com \\ 3 Faculty of Pharmacy, University of Ljubljana, Aškerčeva cesta 7, SI-1000 Ljubljana, Slovenia \\ * Correspondence: zdenko.casar@sandoz.com or zdenko.casar@ffa.uni-lj.si; Tel.: +386-1580-2079
}

check for updates

Citation: Perdih, F.; Žigart, N.; Časar,

Z. Crystal Structure and Solid-State

Conformational Analysis of Active

Pharmaceutical Ingredient

Venetoclax. Crystals 2021, 11, 261.

https://doi.org/10.3390/

cryst11030261

Academic Editor: Etsuo Yonemochi

Received: 18 February 2021

Accepted: 28 February 2021

Published: 7 March 2021

Publisher's Note: MDPI stays neutral with regard to jurisdictional claims in published maps and institutional affiliations.

Copyright: (c) 2021 by the authors. Licensee MDPI, Basel, Switzerland. This article is an open access article distributed under the terms and conditions of the Creative Commons Attribution (CC BY) license (https:// creativecommons.org/licenses/by/ $4.0 /)$.

\begin{abstract}
Venetoclax is an orally bioavailable, B-cell lymphoma-2 selective inhibitor used for the treatment of chronic lymphocytic leukemia, small lymphocytic lymphoma, and acute myeloid leukemia. Venetoclax's crystal structure was until now determined only when it was bound to a Bcell lymphoma-2 (BCL-2) protein, while the crystal structure of this active pharmaceutical ingredient alone has not been reported yet. Herein, we present the first successful crystallization, which provided crystals of venetoclax suitable for X-ray diffraction analysis. The crystal structure of venetoclax hydrate was successfully determined. The asymmetric unit is composed of two crystallographically independent molecules of venetoclax and two molecules of interstitial water. Intramolecular N$\mathrm{H}$.. O hydrogen bonding is present in both molecules, and a molecular overlay shows differences in their molecular conformations, which is also observed in respect to venetoclax molecules from known crystal structures of BCL-2:venetoclax complexes. A supramolecular structure is achieved through various $\mathrm{N}-\mathrm{H} \cdots \mathrm{N}, \mathrm{O}-\mathrm{H} \cdots \mathrm{O}, \mathrm{C}-\mathrm{H} \cdots \mathrm{O}, \mathrm{C}-\mathrm{H} \cdots \pi, \mathrm{C}-\mathrm{Cl} \cdots \pi$, ONO $\cdots \pi$, and $\pi \cdots \pi$ interactions. The obtained crystals were additionally characterized with spectroscopic techniques, such as IR and Raman, as well as with thermal analysis.
\end{abstract}

Keywords: venetoclax; crystals; crystal structure; hydrate; conformation; X-ray diffraction

\section{Introduction}

The B-cell lymphoma-2 (BCL-2) family of proteins, consisting of three distinctive protein groups (anti-apoptotic proteins, pro-apoptotic effectors, and pro-apoptotic initiators/sensitizers), regulate cell death through their direct binding interactions triggering a mitochondrial apoptotic pathway that results in caspase activation and apoptosis [1-16]. BCL-2 anti-apoptotic family members play a key role in cancer cell survival as well as in drug resistance [17-22]. Therefore, they are primary inhibition targets for the treatment of several cancers as their inhibition restores the apoptotic ability of malignant cells [23-27]. Venetoclax (Figure 1) is an orally bioavailable, B-cell lymphoma-2 (BCL-2) selective inhibitor and the first-in-class oral BCL-2 inhibitor for the treatment of lymphoid malignancies [28-35]. Venetoclax was first approved by the FDA in 2016 for the treatment of patients with chronic lymphocytic leukemia (CLL) and later for small lymphocytic lymphoma (SLL) and for the treatment of newly diagnosed acute myeloid leukemia (AML) in combination with azacitidine, decitabine, or low-dose cytarabine [36-39]. According to the IMS Health data, the market value of venetoclax accounted for nearly USD $735 \mathrm{M}$ in 2019. Moreover, there are many ongoing clinical trials involving venetoclax in various combination therapies [40], which puts venetoclax on the list of highly valuable drugs. 


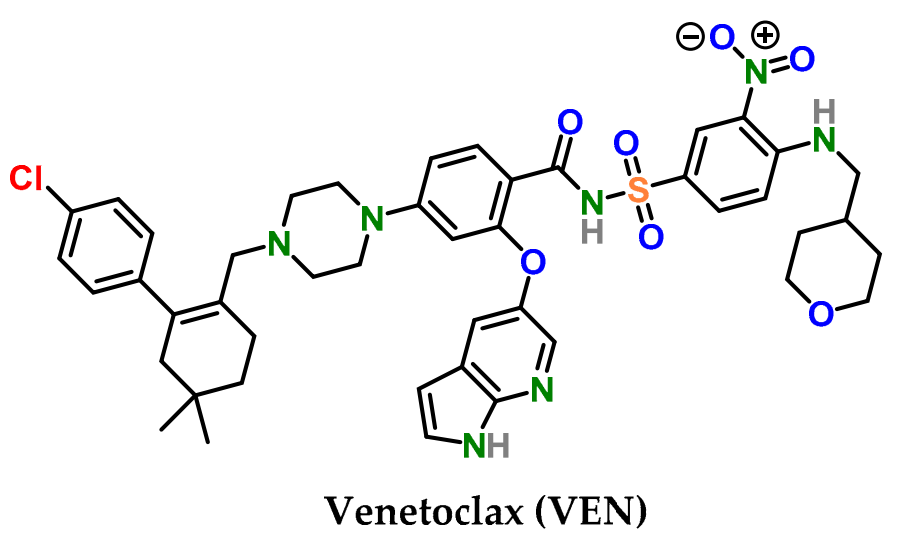

Figure 1. Structure of venetoclax.

Recently, crystal structures of BCL-2 and a BCL-2 mutants bound to venetoclax were reported in the literature [41], which provided the first insights into conformational preferences of venetoclax within the target protein. Surprisingly, although there are several patent literature reports on the salts, polymorphs, hydrates, and solvates of venetoclax [42-44], the crystal structure of active pharmaceutical ingredient venetoclax has not been described in the literature yet. This could be attributed to the well-known challenges related to the growth of single crystals of sufficient size and quality suitable for single crystal X-ray diffraction analysis [45-47]. Since venetoclax (Figure 1) contains several rotatable bonds, it is reasonable to expect that venetoclax could adopt several conformation states with overall rich conformational space. Therefore, the crystal structure of venetoclax could provide new information on the conformations found in a small molecule crystal structure, which could be compared to that of the molecule bound to BCL-2. Such comparison is of high relevance because it could establish if the small molecule crystal conformations are comparable to the protein-bound conformations of venetoclax and therefore relevant to structure-based drug design in this group of compounds. In addition, increasing our knowledge of the conformations adopted by venetoclax could provide a better understanding and exploitation of lesser-known interactions, which could provide more efficient drug design efforts in the future [48-54]. In this report, we provide details on the successful preparation of crystals of venetoclax suitable for single crystal X-ray diffraction analysis, the first crystal structure of venetoclax's hydrate form, and conformational analysis of its small molecule crystal structure in comparison with the venetoclax bound to BCL-2.

\section{Materials and Methods}

\subsection{Materials}

For the purpose of this study, venetoclax was obtained from MSN Laboratories (Hyderabad, India). Acetonitrile (ACN) was purchased from J. T. Baker, now part of Avantor ${ }^{\circledR}$ (Radnor, PA, USA). FTIR grade potassium bromide (KBr) and analytical grade ammonium bicarbonate were purchased from Merck KGaA (Darmstadt, Germany).

\subsection{Characterization Methods}

2.2.1. Attenuated Total Reflection Fourier Transform Infrared (ATR-FTIR) Measurements

ATR-FTIR spectra were collected with a Nicolet iS50FT-IR spectrometer (Thermo Fisher Scientific, Waltham, MA, USA), using a single reflection diamond ATR cell.

\subsubsection{Raman Measurements}

Raman spectra were collected with a Nicolet iS50FT-IR spectrometer (Thermo Fisher Scientific, Waltham, MA, USA), equipped with the iS50 Raman accessory. 


\subsubsection{Differential Scanning Calorimetry (DSC) Measurements}

DSC thermograms were acquired using the differential scanning calorimeter DSC $3^{+}$ Stare System instrument (Mettler Toledo, Polaris Parkway Columbus, OH, USA) operating at $10^{\circ} \mathrm{C} / \mathrm{min}$.

\subsubsection{Thermogravimetric Analysis (TGA) Measurements}

TGA data were acquired using the TGA/DSC 1 Star ${ }^{\mathrm{e}}$ System (Mettler Toledo, Polaris Parkway Columbus, $\mathrm{OH}, \mathrm{USA}$ ) operating at $10^{\circ} \mathrm{C} / \mathrm{min}$.

\subsubsection{X-ray Single Crystal Analysis}

Single crystal X-ray diffraction data of VEN $\cdot \mathbf{H}_{2} \mathbf{O}$ were collected on an Agilent Technologies SuperNova Dual diffractometer (Agilent, UK) with an Atlas detector using monochromated $\mathrm{Cu}-\mathrm{K \alpha}$ radiation $(\lambda=1.54184 \AA)$ at $150 \mathrm{~K}$. The data were processed using CrysAlis Pro [55]. The structure was solved by the SHELXT program [56] and refined by a full-matrix least-squares procedure based on $F^{2}$ with SHELXL [57] using the Olex2 program suite [58]. All non-hydrogen atoms were refined anisotropically. Water atom O16 was refined to be disordered over two positions in a ratio of 0.879(5):0.121(5). Hydrogen atoms were readily located in different Fourier maps, except for the atoms on water oxygen atom $\mathrm{O} 16$ which were not included in the refinement. Hydrogen atoms bonded to carbon atoms were subsequently treated as riding atoms in geometrically idealized positions with $U_{\text {iso }}(\mathrm{H})=k U_{\text {eq }}(\mathrm{C})$, where $k=1.5$ for methyl groups, which were permitted to rotate but not to tilt, and 1.2 for all other $\mathrm{H}$ atoms. Hydrogen atoms bonded to nitrogen and oxygen atoms were refined, fixing the bond lengths and isotropic temperature factors as $U_{\mathrm{iso}}(\mathrm{H})=$ $k U_{\mathrm{eq}}(\mathrm{N}, \mathrm{O})$, where $k=1.2$ in case of $\mathrm{N}$ atoms and 1.5 in case of $\mathrm{O}$ atoms. The hydrogen atom $\mathrm{H} 15 \mathrm{~B}$ on water molecule $\mathrm{O} 15$ had to be treated, fixing the coordinates. The crystallographic data are listed in Table 1.

Table 1. Crystallographic data of venetoclax $\left(\right.$ VEN $\left.\cdot \mathbf{H}_{2} \mathbf{O}\right)$.

\begin{tabular}{|c|c|}
\hline Parameter & $\mathrm{VEN} \cdot \mathrm{H}_{2} \mathrm{O}$ \\
\hline CCDC number & 2063224 \\
\hline Formula & $\mathrm{C}_{45} \mathrm{H}_{50} \mathrm{ClN}_{7} \mathrm{O}_{7} \mathrm{~S} \cdot \mathrm{H}_{2} \mathrm{O}$ \\
\hline$M_{\mathrm{r}}$ & 886.44 \\
\hline$T(\mathrm{~K})$ & $150.00(10)$ \\
\hline Crystal system & triclinic \\
\hline Space group & $P-1$ \\
\hline$a(\AA)$ & $12.6058(3)$ \\
\hline$b(\AA)$ & 13.6947(3) \\
\hline$c(\AA)$ & $26.0490(6)$ \\
\hline$\alpha\left(^{\circ}\right)$ & $83.7790(18)$ \\
\hline$\beta\left(^{\circ}\right)$ & $87.6244(18)$ \\
\hline$\gamma\left({ }^{\circ}\right)$ & 81.3877(18) \\
\hline Volume $\left(\AA^{3}\right)$ & $4418.55(17)$ \\
\hline $\mathrm{Z}$ & 4 \\
\hline$D_{\mathrm{c}}\left(\mathrm{g} / \mathrm{cm}^{3}\right)$ & 1.333 \\
\hline$\mu\left(\mathrm{mm}^{-1}\right)$ & 1.714 \\
\hline$F(000)$ & 1872.0 \\
\hline Reflections collected & 34794 \\
\hline$R_{\text {int }}$ & 0.0305 \\
\hline Data/restraints/parameters & $16756 / 8 / 1152$ \\
\hline$R, w R_{2}[I>2 \sigma(I)]^{a}$ & $0.0463,0.1239$ \\
\hline$R, w R_{2}$ (all data) ${ }^{a}$ & $0.0619,0.1323$ \\
\hline $\mathrm{GOF}, S^{\mathrm{b}}$ & 1.039 \\
\hline Largest diff. peak/hole / e $\AA^{-3}$ & $1.00 /-0.50$ \\
\hline
\end{tabular}

${ }^{a} R=\sum|| F_{\mathrm{o}}|-| F_{\mathrm{c}}|| / \sum\left|F_{\mathrm{o}}\right|, w R_{2}=\left\{\sum\left[w\left(F_{\mathrm{o}}{ }^{2}-F_{\mathrm{c}}{ }^{2}\right)^{2}\right] / \sum\left[w\left(F_{\mathrm{o}}{ }^{2}\right)^{2}\right]\right\}^{1 / 2} \cdot{ }^{b} S=\left\{\sum\left[\left(F_{\mathrm{o}}{ }^{2}-F_{\mathrm{c}}{ }^{2}\right)^{2}\right] /(n-p)\right\}^{1 / 2}$, where $n$ is the number of reflections and $p$ is the total number of refined parameters. 


\subsubsection{Powder X-ray Diffraction Analysis}

Powder X-ray diffraction pattern ( $p$-XRD) of prepared $\mathbf{V E N} \cdot \mathbf{H}_{\mathbf{2}} \mathbf{O}$ was obtained with an X'Pert PRO diffractometer (PANalytical, Almelo, Netherlands) equipped with a $\mathrm{Ge}(111)$ Johannson type monochromator in reflection mode using CuKa1 radiation $(\lambda=1.54060 \AA)$ and the full range of the 128 channel linear RTMS detector. The diffractogram was recorded at a tube voltage of $45 \mathrm{kV}$, tube current of $40 \mathrm{~mA}$, and applying a step size of $0.034^{\circ} 2 \theta$ with an exposure time of $100 \mathrm{~s}$ per step in the angular range of $3^{\circ}$ to $50^{\circ} 2 \theta$ under ambient conditions. Since no characteristic reflections were visible above $40^{\circ} 2 \theta$, the diffractogram is shown in the range of $3-40^{\circ} 2 \theta$.

\subsection{Synthesis and Characterization of Venetoclax Hydrate}

Venetoclax (100 mg) was placed into an Erlenmeyer flask and $100 \mathrm{~mL}$ of ACN$\mathrm{NH}_{4} \mathrm{HCO}_{3}(10 \mathrm{mM}$ solution $)=8: 2$ solvent mixture was added. The obtained suspension was sonicated in an ultrasonic bath for 5 minutes. The obtained turbid solution was left to stand at ambient temperature for 2 hours and then filtered through a polytetrafluoroethylene (PTFE) filter. The obtained yellow solution was placed into a glass laboratory bottle and left to stand unclosed at ambient temperature for 60 days. During this time, the solvent evaporated affording agglomerated crystals on the bottom of the bottle and needle-shaped crystals that were deposited on the walls of the glass bottle. The agglomerated crystals on the bottom of the glass bottle were discarded while the needle-like crystals suitable for the single crystal X-ray analysis obtained from the walls of the glass bottle were collected for further analysis. DSC $\left(10^{\circ} \mathrm{K} / \mathrm{min}\right): 49^{\circ} \mathrm{C}$ onset, $64^{\circ} \mathrm{C}$ peak (endothermic transition) and $168{ }^{\circ} \mathrm{C}$ onset, $182{ }^{\circ} \mathrm{C}$ peak (endothermic transition); ATR-FTIR: 565, 663, 734, 760, 816, 831, $865,902,985,1098,1125,1141,1171,1231,1244,1255,1346,1410,1434,1521,1569,1578$, 1607, 1677, 2842, 2917, 3303, $3364 \mathrm{~cm}^{-1}$; Raman: 796, 838, 1068, 1142, 1161, 1172, 1232, 1272, $1363,1427,1496,1607,1678,2847,2892,2919,2941,2961,3065,3083 \mathrm{~cm}^{-1} ; p-X R D(C u-K \alpha)$ : 6.5, 7.0, 7.7, 9.8, 10.8, 11.4, 11.7, 12.6, 13.1, 14.3, 15.6, 16.7, 16.8, 17.3, 17.7, 18.2, 18.5, 19.9, $20.0,20.5,21.4,21.9,22.5,23.0,23.4,24.3,24.9,26.1,26.4,28.7,29.2,29.5^{\circ} 2 \theta$.

\section{Results and Discussion}

\subsection{Preparation of Venetoclax Hydrate}

In our previous studies on the stability and liquid chromatography analytical method development for venetoclax, we observed that venetoclax formed crystals after a few days from some of the solvents used for the dissolution of venetoclax $[59,60]$. Therefore, we performed a targeted crystallization experiment from the most promising solvent system identified in our previous study [60]. For this purpose, venetoclax was dissolved in an $\mathrm{ACN}-\mathrm{NH}_{4} \mathrm{HCO}_{3}(10 \mathrm{mM}$ solution $)=8: 2$ solvent mixture, and the solution was left to stand for 60 days at ambient temperature in a laboratory glass bottle. The yellow needle-shaped crystals that were formed on the walls of the glass bottle after evaporation of the solvent were collected and used for further analysis. This proved that the obtained crystalline venetoclax was suitable for single crystal X-ray diffraction. Thermal analysis and $X$-ray data indicated that the obtained crystals represented a venetoclax hydrate form that was previously reported in the patent literature, although it was obtained by desolvation of the venetoclax ethyl acetate solvate at ambient conditions and characterized only with a $p$-XRD [42].

\subsection{Characterization of Venetoclax Hydrate}

\subsubsection{Infrared Spectral Analysis}

In the IR spectrum of venetoclax hydrate (Figure 2) the most diagnostic bands are associated with the shoulder of an $\mathrm{OH}$ band of water in the $3700-3400 \mathrm{~cm}^{-1}$ region, $\mathrm{N}-\mathrm{H}$ stretching vibrations ( 3364 and $3303 \mathrm{~cm}^{-1}$ ), $\mathrm{C}-\mathrm{H}$ stretching vibrations of the benzene rings (3141 and $3105 \mathrm{~cm}^{-1}$ ), $\mathrm{C}-\mathrm{H}$ stretching vibrations of $\mathrm{CH}_{2}$ and $\mathrm{CH}_{3}$ groups (2917 and $\left.2842 \mathrm{~cm}^{-1}\right), \mathrm{C}=\mathrm{O}$ stretching vibration of an amide bond $\left(1677 \mathrm{~cm}^{-1}\right)$, and stretching 
vibrations that are probably associated with $\mathrm{C}=\mathrm{C}$ aromatic rings, the $-\mathrm{NO}_{2}$ group, and the $-\mathrm{SO}_{2}$ group $\left(1607,1569,1521,1362,1346\right.$ and $\left.1141 \mathrm{~cm}^{-1}\right)$.

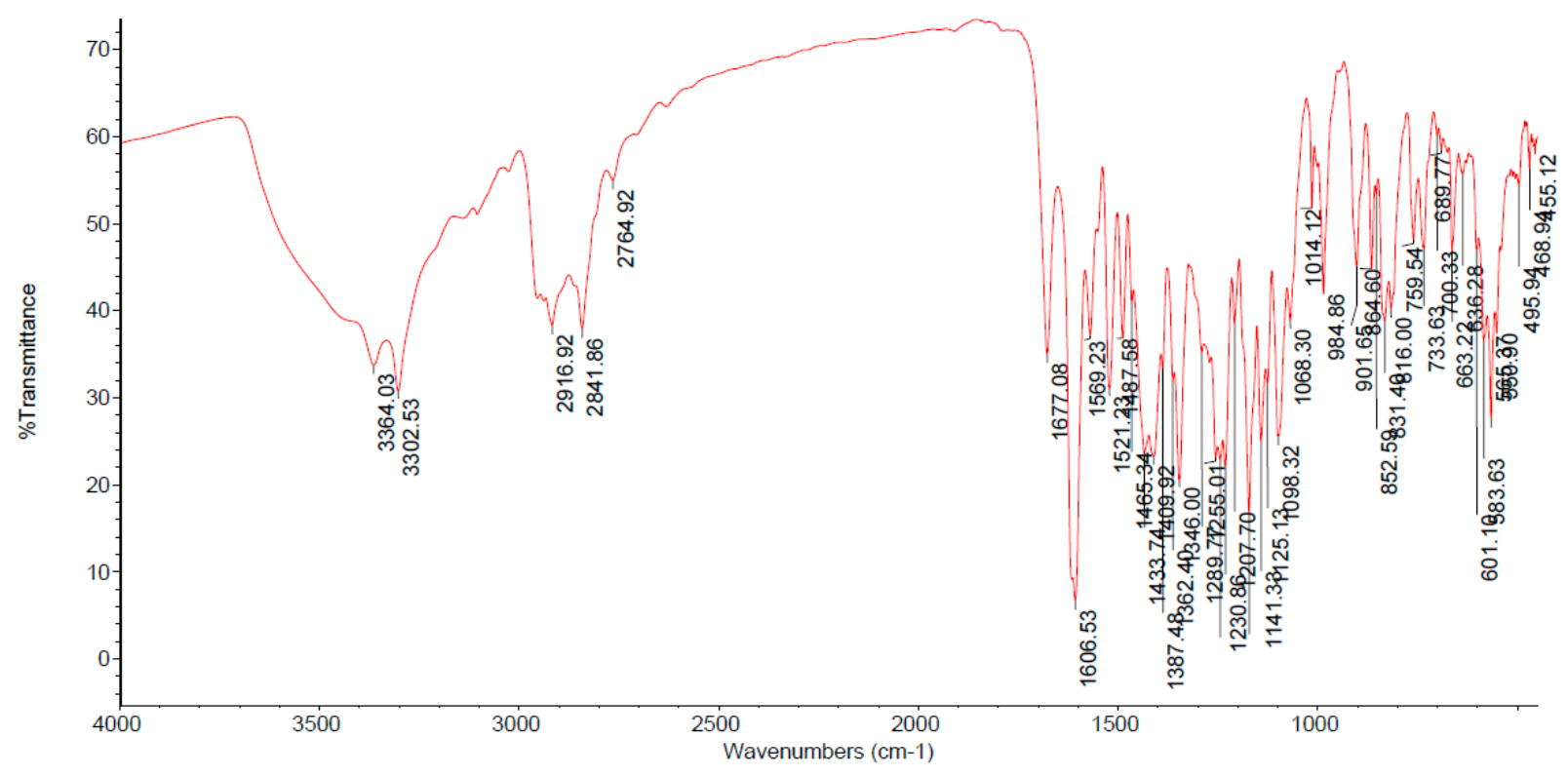

Figure 2. IR spectrum of VEN $\cdot \mathrm{H}_{2} \mathrm{O}$.

\subsubsection{Raman Spectral Analysis}

The Raman spectrum of venetoclax hydrate (Figure 3) displays $\mathrm{CH}$ stretching of unsaturated carbons in the region above $3000 \mathrm{~cm}^{-1}$, while $\mathrm{CH}$ stretching of saturated carbons populates the region from 3000 to $2840 \mathrm{~cm}^{-1}$. The most diagnostic bands in the Raman spectrum are located at $1678 \mathrm{~cm}^{-1}$ ( $\mathrm{C}=\mathrm{O}$ stretch of an amide bond) and a very strong aryl $C=C$ stretch $1607 \mathrm{~cm}^{-1}$.

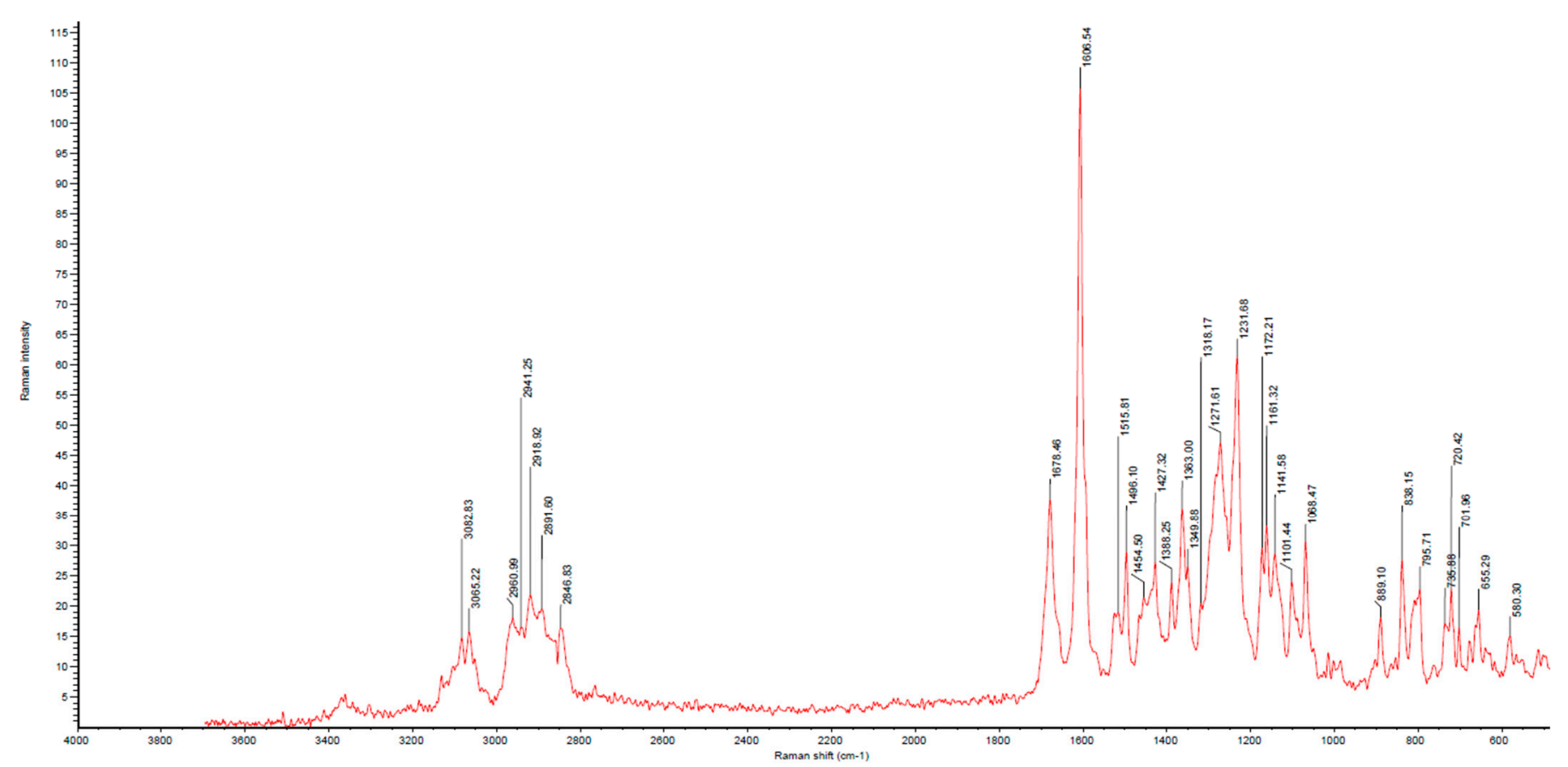

Figure 3. Raman spectrum of VEN $\cdot \mathrm{H}_{2} \mathrm{O}$. 


\subsubsection{Thermal Analyses}

The thermal behavior of the obtained crystalline venetoclax is shown in Figure 4 . In the DSC thermogram (Figure 4, top), two endothermic transitions were observed: the first transition at $49{ }^{\circ} \mathrm{C}$ (onset) and $64{ }^{\circ} \mathrm{C}$ (peak), which is probably associated with partial dehydration, and the second transition at $168^{\circ} \mathrm{C}$ (onset) and $182{ }^{\circ} \mathrm{C}$ (peak), which is probably associated with the melting of the form obtained after dehydration. After both endothermic phenomena, an exothermic transition peak associated with decomposition was observed at temperatures above $220^{\circ} \mathrm{C}$. The TGA thermogram (Figure 4, bottom) indicates that dehydration starts above $30^{\circ} \mathrm{C}$ and the mass loss is completed by $200^{\circ} \mathrm{C}$. The mass loss of $1.92 \% w / w$ is well within the expected value for a monohydrate form, i.e., $2.03 \% w / w$. Thus, TGA and DSC data on the obtained crystalline solid venetoclax indicated that this is a hydrated form of venetoclax.

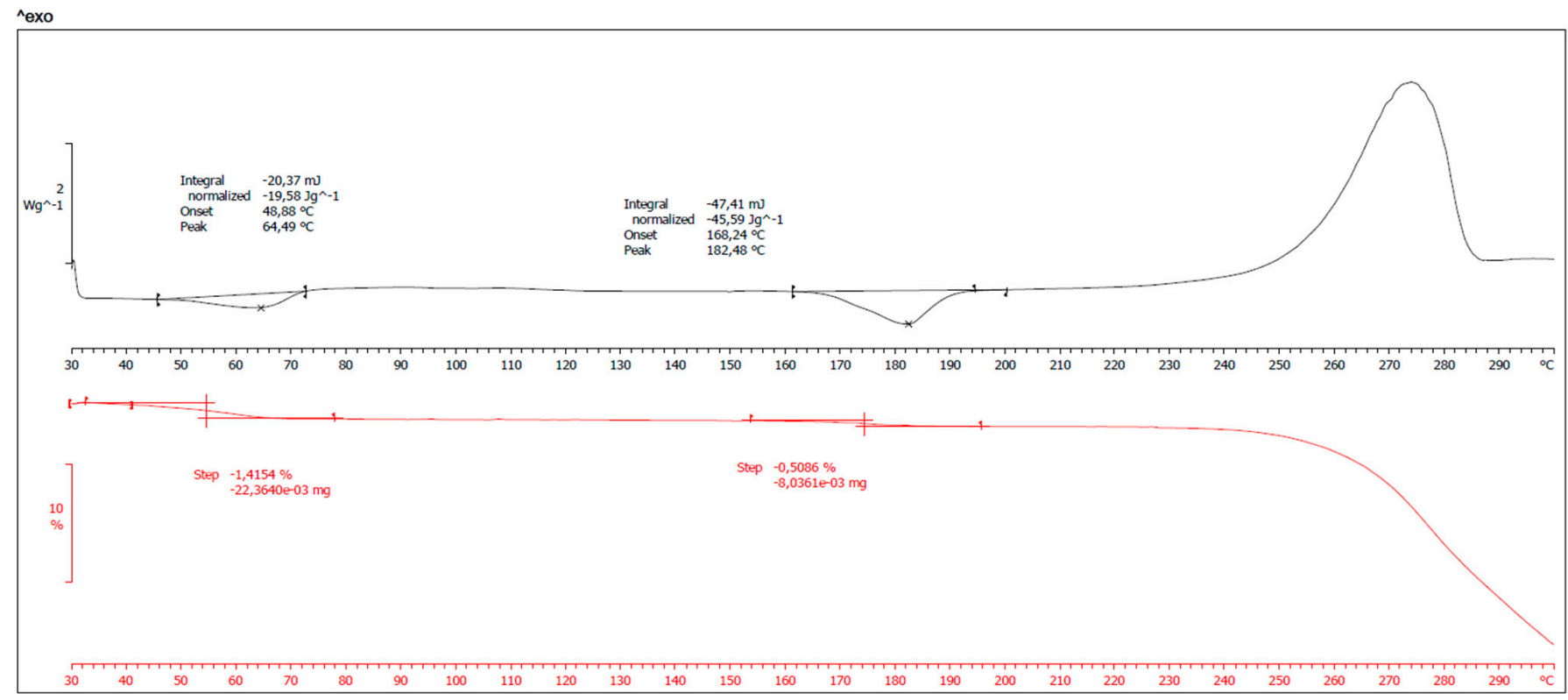

Figure 4. DSC and TGA thermograms of VEN $\cdot \mathrm{H}_{2} \mathrm{O}$.

\subsubsection{Powder X-ray Diffraction Analysis}

To investigate whether the analyzed crystal structure is truly representative of the bulk material, the X-ray powder diffraction ( $p$-XRD) technique wasperformed at room temperature and compared with the pattern simulated from the crystal structure. As depicted in Figure 5, the experimental $p$-XRD pattern is nearly identical with the corresponding simulated one except for some differences that may be due to the preferential orientation. The studied form has a $p$-XRD comparable to the previously reported monohydrate form in the patent literature [42]. 


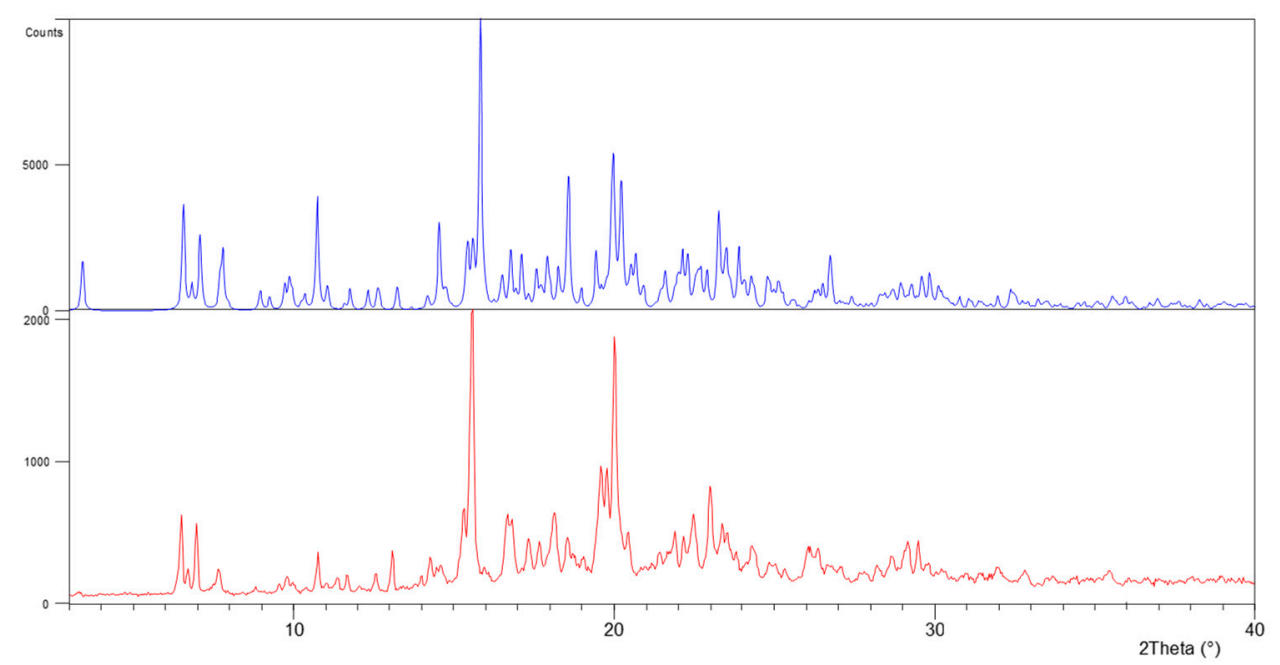

Figure 5. Simulated (blue) and experimental (red) powder X-ray diffraction pattern of VEN· $\mathbf{H}_{2} \mathbf{O}$.

\subsubsection{X-ray Single Crystal Analysis}

- Molecular Geometry

Needle-shaped crystals of venetoclax, suitable for single crystal X-ray diffraction, were prepared by crystallization from an $\mathrm{ACN}$-aqueous ammonium bicarbonate buffer system. Thermal analysis and X-ray data indicated that the crystals obtained represented a venetoclax hydrate form [42] that was previously described only in the patent literature and characterized solely with a $p$-XRD analysis. Crystallographic data are listed in Table 1 (see supplementary material for further details). The compound VEN $\cdot \mathbf{H}_{\mathbf{2}} \mathbf{O}$ crystalizes in triclinic space group $P-1$ with two crystallographically independent molecules of venetoclax (A and $B$ ) and two molecules of interstitial water in the asymmetric unit, with one (O16) being disordered over two positions (Figure 6a). In each molecule (A and B), intramolecular $\mathrm{N}-\mathrm{H} \cdots$ ONO hydrogen bonding between the amine group (N3, N10) and nitro group, as well as intramolecular $\mathrm{N}-\mathrm{H}$. . O hydrogen bonding between the amide group (N1, $\mathrm{N} 8)$ and phenyl oxygen atom $(\mathrm{O} 7, \mathrm{O} 14)$, are present and stabilize the molecular structure (Table 2, Figure $6 \mathrm{~b}, \mathrm{c}$ ).

Table 2. Hydrogen bonds for $\mathrm{VEN} \cdot \mathrm{H}_{2} \mathrm{O}\left[\AA\right.$ and $\left.^{\circ}\right]$.

\begin{tabular}{|c|c|c|c|c|}
\hline D-H $\cdots A$ & $d(\mathrm{D}-\mathrm{H})$ & $\mathrm{d}(\mathrm{H} \cdots \mathrm{A})$ & $\mathrm{d}(\mathrm{D} \cdots \mathrm{A})$ & $<$ (DHA) \\
\hline $\mathrm{N} 1-\mathrm{H} 1 \cdots \mathrm{O} 7$ & $0.833(17)$ & $1.97(2)$ & $2.602(2)$ & $132(2)$ \\
\hline N3-H3 $\cdots$ O5 & $0.848(17)$ & $2.01(2)$ & $2.636(2)$ & $130(2)$ \\
\hline $\mathrm{N} 5-\mathrm{H} 5 \cdots \mathrm{N} 4^{\mathrm{i}}$ & $0.864(17)$ & $2.041(18)$ & $2.891(3)$ & 168(3) \\
\hline $\mathrm{C} 15-\mathrm{H} 15 \cdots \mathrm{O} 13^{\mathrm{ii}}$ & 1.00 & 2.55 & $3.375(3)$ & 139.3 \\
\hline $\mathrm{C} 27-\mathrm{H} 27 \mathrm{~A} \cdots \mathrm{O} 4^{\mathrm{iii}}$ & 0.99 & 2.43 & $3.368(3)$ & 157.1 \\
\hline $\mathrm{C} 29-\mathrm{H} 29 \mathrm{~A} \cdots \mathrm{O}^{\mathrm{iv}}$ & 0.99 & 2.48 & $3.456(3)$ & 166.9 \\
\hline C29-H29B $\cdots$ O16B ${ }^{\mathrm{ii}}$ & 0.99 & 2.51 & $3.393(13)$ & 148.8 \\
\hline C31-H31A... O12 & 0.99 & 2.50 & $3.292(3)$ & 136.8 \\
\hline C31-H31A... N9 & 0.99 & 2.61 & $3.310(3)$ & 128.1 \\
\hline C39-H39..OO $1^{\mathrm{iii}}$ & 0.95 & 2.55 & $3.244(2)$ & 130.5 \\
\hline C45-H45A … O16B & 0.98 & 2.48 & $3.429(14)$ & 163.8 \\
\hline N8-H8 $\cdots \mathrm{O} 14$ & $0.880(17)$ & $1.90(2)$ & $2.650(3)$ & $141(3)$ \\
\hline N10-H10 . . O12 & $0.879(18)$ & $2.05(3)$ & $2.665(3)$ & $127(3)$ \\
\hline $\mathrm{N} 12-\mathrm{H} 12 \mathrm{~A} \cdots \mathrm{O} 11^{\mathrm{v}}$ & $0.870(17)$ & $2.25(2)$ & $3.070(3)$ & $157(3)$ \\
\hline C51-H51 ․ O16B & 0.95 & 2.47 & $3.328(13)$ & 150.3 \\
\hline C61-H61B $\cdots$ O10 & 0.99 & 2.58 & $3.330(3)$ & 132.5 \\
\hline $\mathrm{C} 71-\mathrm{H} 71 \cdots \mathrm{O} 15^{\mathrm{vii}}$ & 0.95 & 2.55 & $3.483(3)$ & 168.8 \\
\hline O15-H15A ‥ O16A & $0.871(10)$ & $2.18(3)$ & $2.890(4)$ & $139(4)$ \\
\hline O15-H15A … O16B & $0.871(10)$ & $2.03(3)$ & $2.843(14)$ & $156(5)$ \\
\hline O15-H15B . O O9viii & $0.858(3)$ & $2.330(2)$ & $3.170(3)$ & $166.0(2)$ \\
\hline
\end{tabular}

Symmetry codes: (i) $-x,-y+1,-z$; (ii) $x-1, y, z$; (iii) $x+1, y, z$; (iv) $x+1, y-1, z$; (v) $x, y+1, z$; (vi) $-x,-y+1,-z+1$; (vii) $x-1, y+1, z$; (viii) $-x+1,-y,-z+1$. 


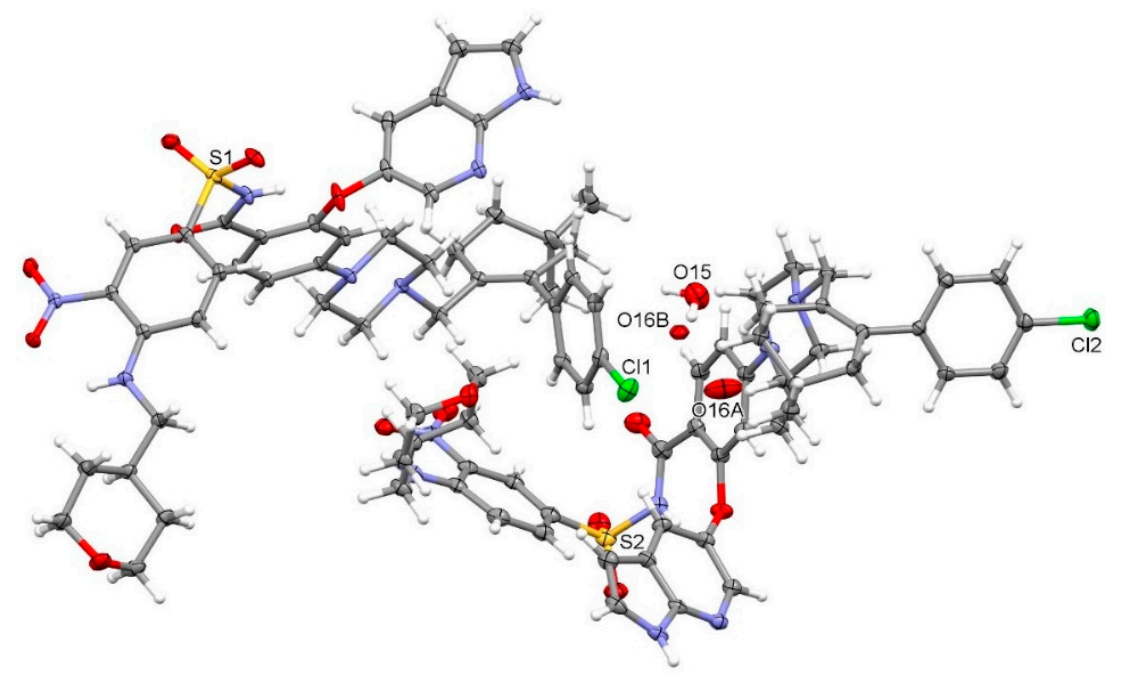

(a)

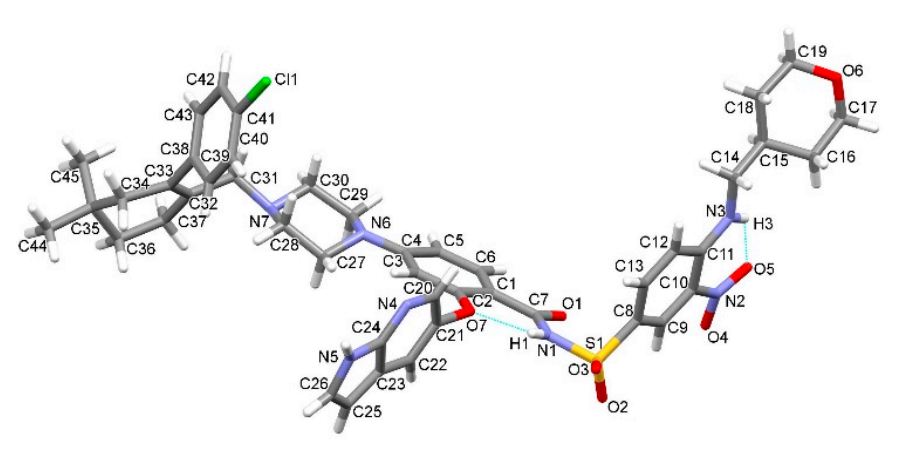

(b)

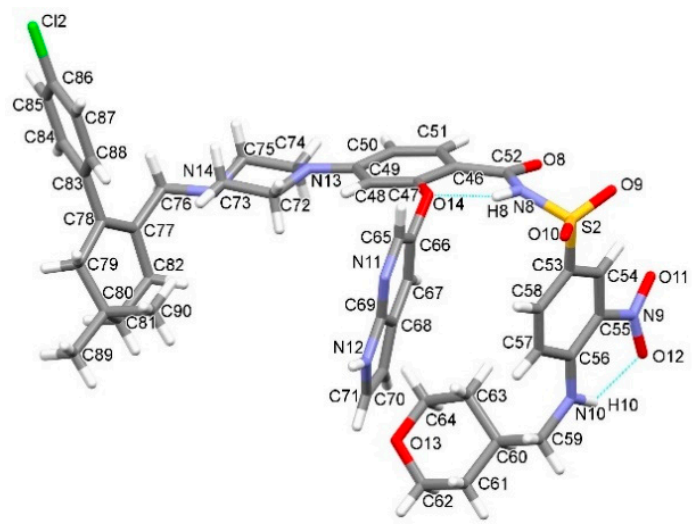

(c)

Figure 6. (a) Thermal ellipsoid figure of an asymmetric unit of $\mathbf{V E N} \cdot \mathbf{H}_{\mathbf{2}} \mathbf{O}$ drawn at the $30 \%$ probability level. Asymmetric unit contains two crystallographically independent molecules of venetoclax and two water molecules (O15, O16 in disorder). (b) Molecule A and (c) molecule B of $\mathbf{V E N} \cdot \mathbf{H}_{2} \mathbf{O}$ with an atom numbering scheme. Intramolecular hydrogen bonds are drawn with dashed blue lines.

The molecular overlay shows that the main difference between molecules $\mathrm{A}$ and $\mathrm{B}$ is in the orientation of the nitrobenzenesulfonyl moiety with C-S-N-C torsion angle $\left(\Phi_{1}\right)$ of $57.09(19)^{\circ}$ (molecule A) vs. $-57.7(2)^{\circ}$ (molecule B) with the additional difference in $\mathrm{C}-\mathrm{N}-\mathrm{C}-\mathrm{C}$ torsion angle $\left(\Phi_{2}\right)$ of the terminal tetrahydropyranyl substituent of $-170.15(18)^{\circ}$ (A) vs. $97.6(3)^{\circ}$ (B) (Figure 7). Some difference in the inclination of the chlorophenylcyclohexenyl moiety is also evident with the $\mathrm{N}-\mathrm{C}-\mathrm{C}-\mathrm{C}$ torsion angle $\left(\Phi_{3}\right)$ being $110.2(2)^{\circ}(\mathrm{A})$ and $113.7(2)^{\circ}(\mathrm{B})$, with the quaternary atom $\mathrm{C} 35$ (molecule $\mathrm{A}$ ) being oriented away from the $1 H$-pyrrolopyridine moiety, while atom C 80 (molecule B) is being oriented toward to this moiety. Furthermore, the difference observed between the two conformations is also due to the inclination of the $1 H$-pyrrolopyridine-containing substituent in respect of the benzamide scaffold with the $\mathrm{C}-\mathrm{C}-\mathrm{O}-\mathrm{C}$ torsion angle $\left(\Phi_{4}\right)$ being $18.1(3)^{\circ}$ for $\mathrm{A}$ and $51.6(3)^{\circ}$ for $\mathrm{B}$. In molecule $\mathrm{B}$, the $1 \mathrm{H}$-pyrrolopyridine moiety is thus in close proximity of the nitrobenzenesulfonyl and tetrahydropyranyl rings. 


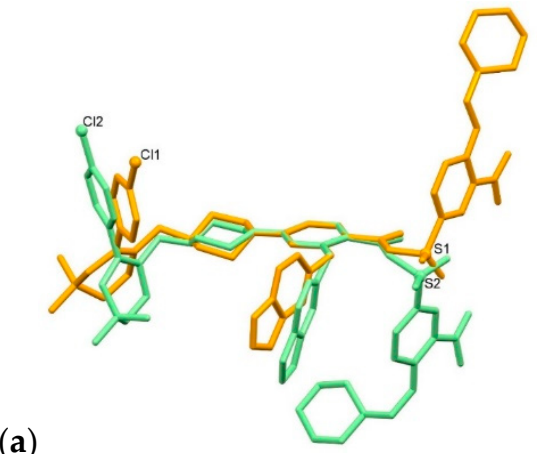

(a)

Figure 7. (a) Superposition showing the difference in conformation of venetoclax molecules A (orange) and B (light green). For clarity, hydrogen atoms are omitted, and $\mathrm{Cl}$ and $\mathrm{S}$ atoms are drawn as small spheres. (b) Selected torsion angles highlighted.

Molecule A forms a hydrogen bonded centrosymmetric dimer via N5-H5 $\cdots \mathrm{N} 4^{\mathrm{i}}$ interactions between adjacent $1 \mathrm{H}$-pyrrolopyridine moieties with the graph-set motif $\mathrm{R}_{2}{ }^{2}(8)$ [61] (Table 2, Figure 8). Dimers are further connected into a chain along the $a$-axis via C27$\mathrm{H} 27 \mathrm{~A} \cdots \mathrm{O} 4^{\mathrm{iii}}$ interactions between the piperazine moiety and nitro group as well as via

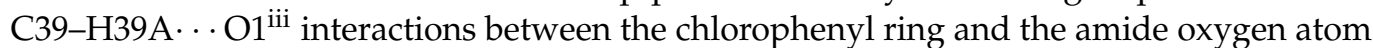
forming a graph-set motif $\mathrm{R}_{2}{ }^{2}(19)$. This interaction is supported by almost parallel $\pi \cdots \pi$ interactions between each ring of the $1 H$-pyrrolopyridine moiety and the nitrophenyl ring of the adjacent molecule with a centroid-to-centroid distance of 3.8869(13) and 3.8873(12) $\AA$ and ring slippage of 2.037 and $2.016 \AA$, respectively. Moreover, $\mathrm{ONO} \cdots \pi$ interactions are present between the nitro group and the pyridine ring of the $1 H$-pyrrolopyridine moiety with an $\mathrm{O} \cdots \pi$ distance of 3.0931(19) $\AA$. The chains are further connected into a layer along the $a b$-plane via $\mathrm{C} 29-\mathrm{H} 29 \mathrm{~A} \cdots \mathrm{O}^{\mathrm{iv}}$ interactions between the piperazine moiety and the tetrahydropyrane oxygen atom of the adjacent molecule.

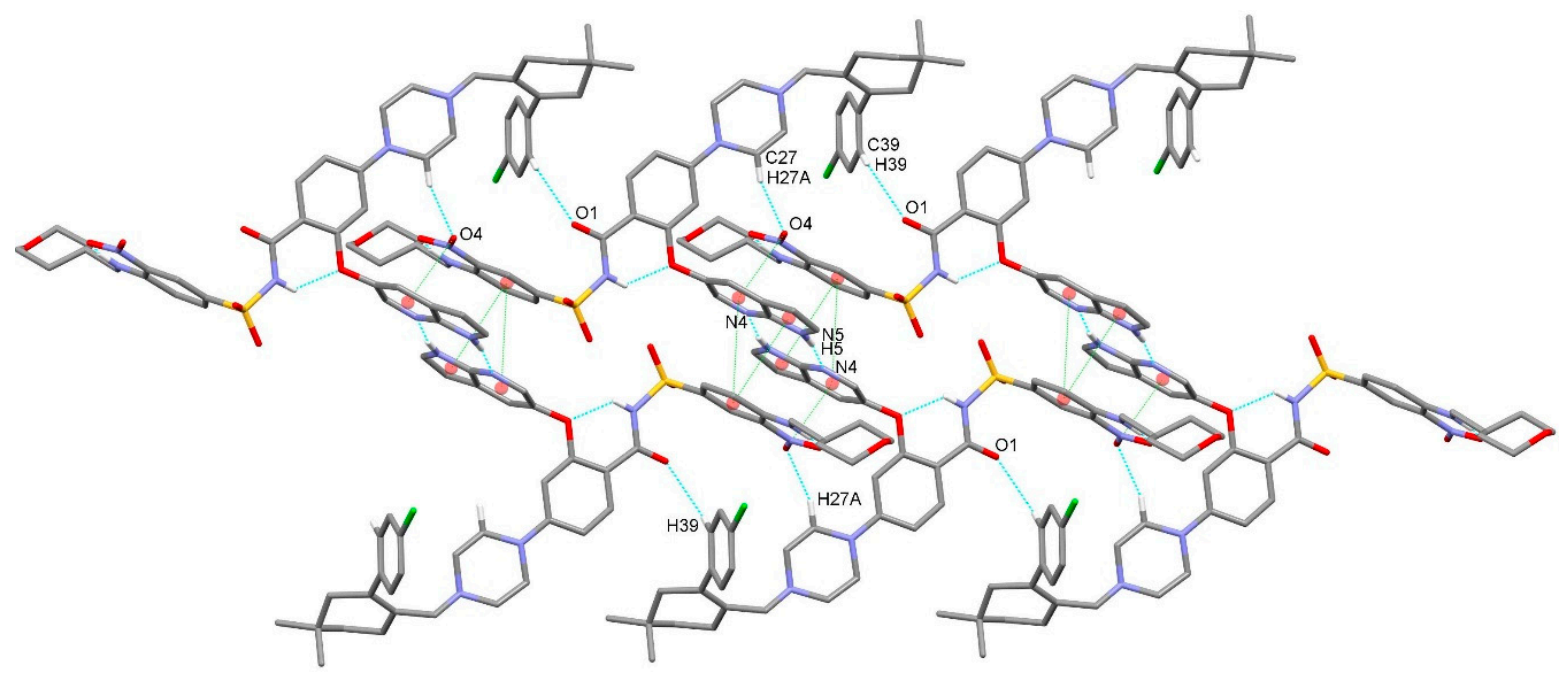

(a)

Figure 8. Cont. 


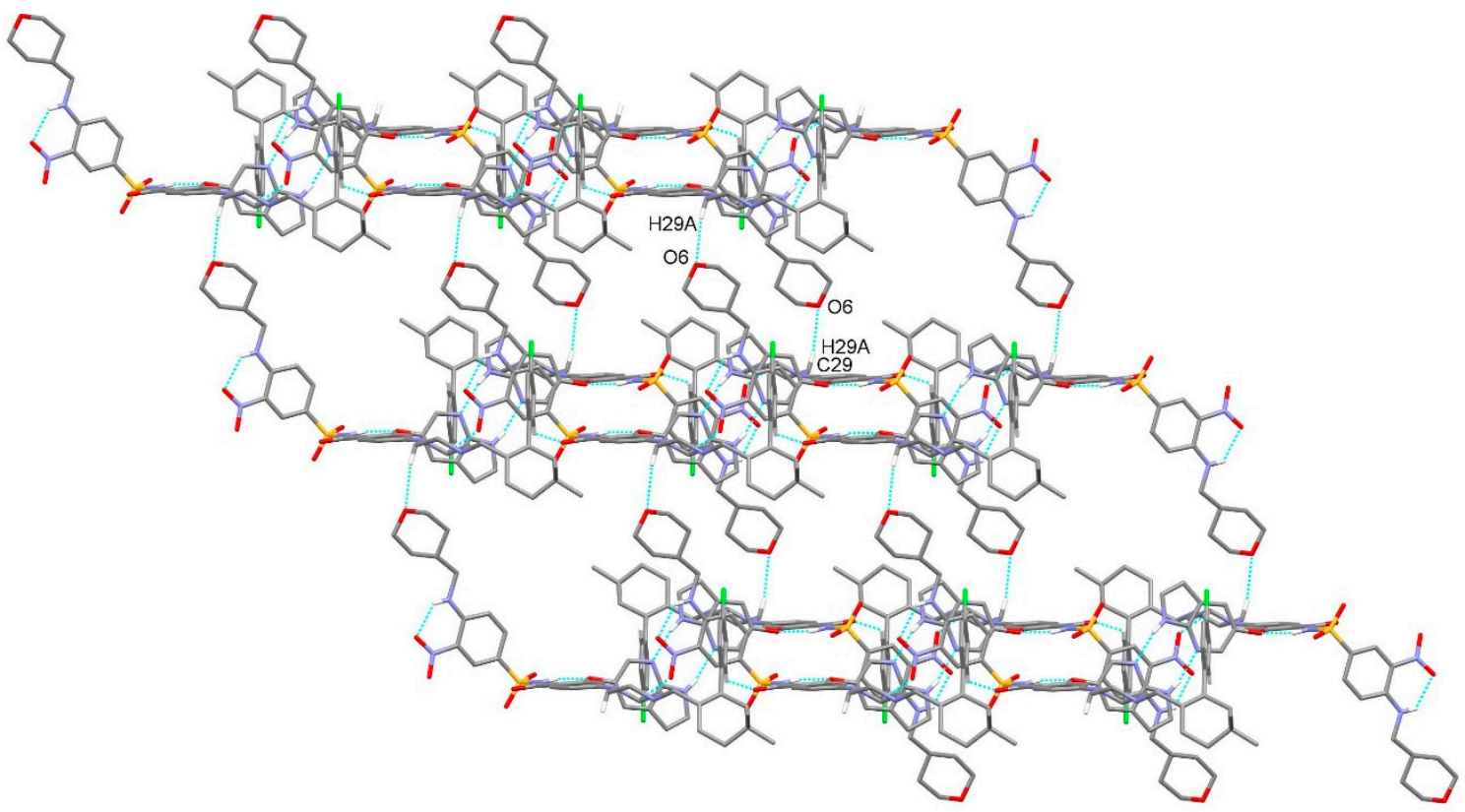

(b)

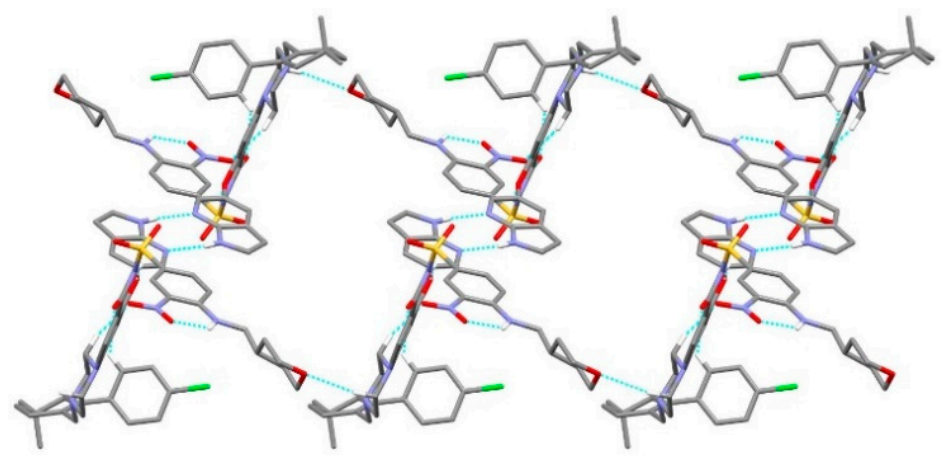

(c)

Figure 8. Crystal architecture formed by molecules of A in $\mathbf{V E N} \cdot \mathbf{H}_{2} \mathbf{O}$. (a) Hydrogen bonded dimers formed via N5$\mathrm{H} 5 \cdots \mathrm{N} 4^{\mathrm{i}}$ interactions connected into a chain along the $a$-axis via $\mathrm{C} 27-\mathrm{H} 27 \mathrm{~A} \cdots \mathrm{O} 4^{\mathrm{iii}}, \pi \cdots \pi$, and ONO $\cdots \pi$ interactions; (b) layer formation via C29-H29A ... O $6^{\text {iv }}$ interactions; and (c) view of a layer along the $a$-axis. Hydrogen bonds are drawn by dashed blue lines and $\pi \cdots \pi$ and ONO $\cdots \pi$ interactions by dashed green lines (presented only in (a) for clarity). Hydrogen atoms not involved in the motif shown have been omitted for clarity.

In contrast to molecules of $\mathrm{A}$, where the centrosymmetric hydrogen bonded dimer between the adjacent $1 \mathrm{H}$-pyrrolopyridine units is formed, molecules of $\mathrm{B}$ form a chain along the $b$-axis through $\mathrm{N} 12-\mathrm{H} 12 \cdots \mathrm{O} 11^{\mathrm{v}}$ interactions with the $1 \mathrm{H}$-pyrrolopyridine moiety acting as a hydrogen bond donor and the nitro group of the adjacent molecule as a hydrogen bond acceptor (Table 2, Figure 9a). Two such chains are connected into a belt via centrosymmetric $\mathrm{C} 61-\mathrm{H} 61 \cdots \mathrm{O} 10^{\mathrm{vi}}$ interactions between the tetrahydropyranyl methylene group and the sulfonyl oxygen atom, forming a graph-set motif $\mathrm{R}_{2}{ }^{2}(22)$. The belt structure is supported by $\pi \cdots \pi$ interactions between the pyrrole ring of the $1 H$-pyrrolopyridine moiety and the nitrophenyl ring of the adjacent molecule with a centroid-to-centroid distance of 3.860(1) $\AA$ and an angle between both rings of $25.4(1)^{\circ}$. The belts are further connected into a layer along the $a b$-plane via $\mathrm{C} 61-\mathrm{H} 61 \mathrm{~A} \cdots \pi$ interactions between the tetrahydropyranyl methylene group and the C46-C51 aromatic system (Figure 9b). 


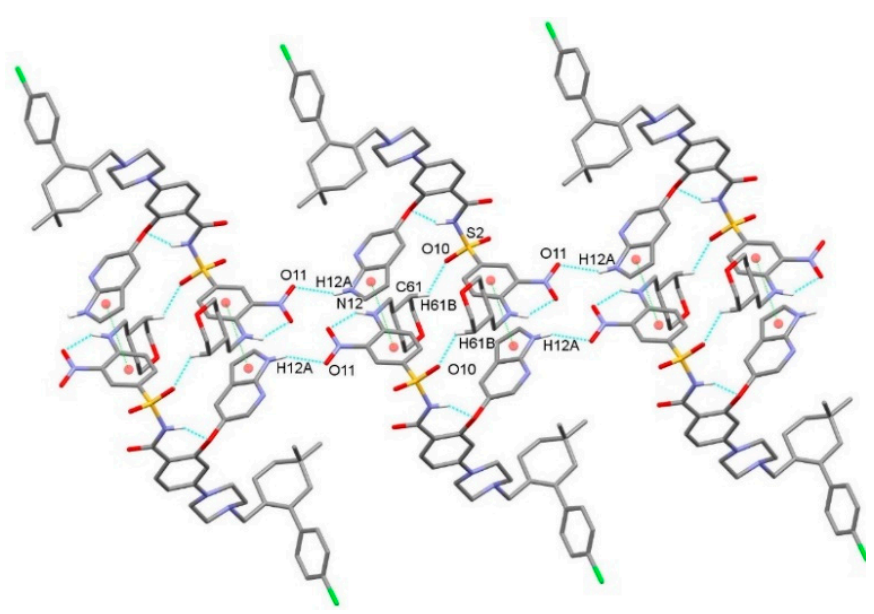

(a)

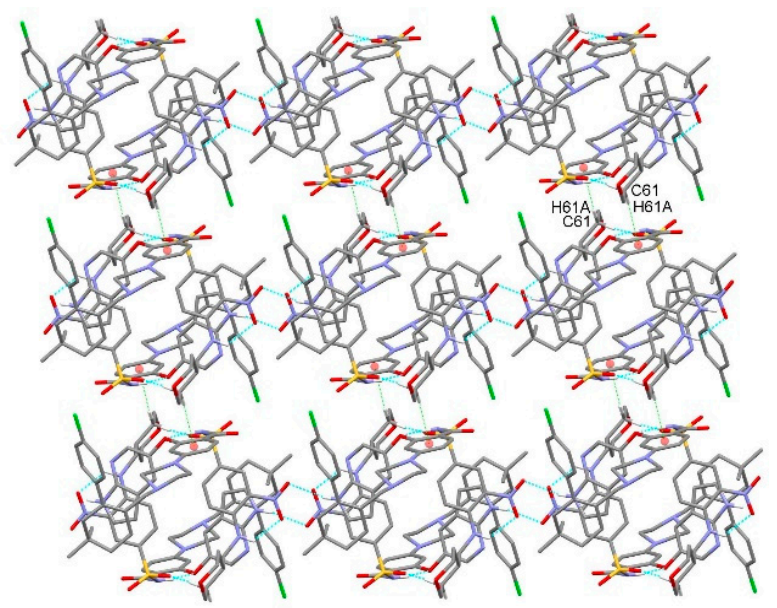

(b)

Figure 9. Crystal architecture formed by molecules of $\mathrm{B}$ in $\mathbf{V E N} \cdot \mathbf{H}_{2} \mathbf{O}$. (a) Belt formation along the $b$-axis formed via $\mathrm{N} 12-\mathrm{H} 12 \cdots \mathrm{O} 11^{\mathrm{v}}, \mathrm{C} 61-\mathrm{H} 61 \mathrm{~B} \cdots \mathrm{O} 10^{\mathrm{vi}}$, and $\pi \cdots \pi$ interactions. (b) Layer formation along the $a b$-plane via C61-H61A $\cdots \pi$ interactions. Hydrogen bonds are drawn by dashed blue lines and $\pi \cdots \pi$ and $\mathrm{C}-\mathrm{H} \cdots \pi$ interactions by dashed green lines. Hydrogen atoms not involved in the motif shown have been omitted for clarity.

\section{- $\quad$ Crystal Packing}

The supramolecular structure of VEN $\cdot \mathbf{H}_{2} \mathbf{O}$ is achieved through $\mathrm{C}-\mathrm{H} \cdots \mathrm{O}, \mathrm{C}-\mathrm{H} \cdots \pi$, and $\mathrm{C}-\mathrm{Cl} \cdots \pi$ interactions between layers of molecules of $\mathrm{A}$ and layers of molecules of B (Table 2, Figure 10). Molecules of A act as hydrogen bond donors and molecules of $\mathrm{B}$ as acceptors through $\mathrm{C} 15-\mathrm{H} 15 \cdots \mathrm{O} 13^{\mathrm{ii}}$ interactions connecting the methine group of a tetrahydropyranyl ring with the oxygen atom of tetrahydropyranyl and through C31$\mathrm{H} 31 \mathrm{~A}$... O12 interactions connecting the methylene unit attached to the piperazine moiety and the nitro group. Furthermore, $\mathrm{C} 37-\mathrm{H} 37 \cdots \pi$ interactions connect the methylene unit of the cyclohexenyl ring of molecules of A with the pyrrole ring of molecules of $\mathrm{B}$, while $\mathrm{C} 41$ $\mathrm{Cl1} \cdots \pi$ interactions are present between molecules of $\mathrm{A}$ and the benzene ring $\mathrm{C} 46-\mathrm{C} 51$ of molecules of B. Furthermore, C $87-\mathrm{H} 87 \cdots \pi$ interactions connect the chlorobenzene moiety of molecules of $\mathrm{B}$ with the benzene ring $\mathrm{C} 1-\mathrm{C} 6$ of molecules of A. Venetoclax crystalizes in a form of monohydrate with two water molecules in the asymmetric unit. These water molecules are also involved in supramolecular aggregation. Water molecule $\mathrm{O} 15$ acts as a hydrogen bond donor in the interaction with the disordered water molecule O16 (O15H15A … O16A, O15-H15A ‥ O16B) and in the interaction with the sulfonyl O9 atom of molecule $\mathrm{B}$ as well as a hydrogen bond acceptor in the C71-H71 . . O15 interaction with the pyrrole ring of molecule B. Hydrogen atoms on the disordered water molecule $\mathrm{O} 16$ were not found in the Fourier maps; however, O16B $\cdots$ O9 and O16A $\cdots$ N11 separations of 2.79 and $2.94 \AA$, respectively, indicate hydrogen bonding interactions with molecules of $\mathrm{B}$. In addition, water molecule O16B is a hydrogen bond acceptor in $\mathrm{C} 29-\mathrm{H} 29 \mathrm{~B} \cdots \mathrm{O} 16 \mathrm{~B}$, C45-H45A $\cdots$ O16B, and C51-H51 ‥ O16B interactions. 


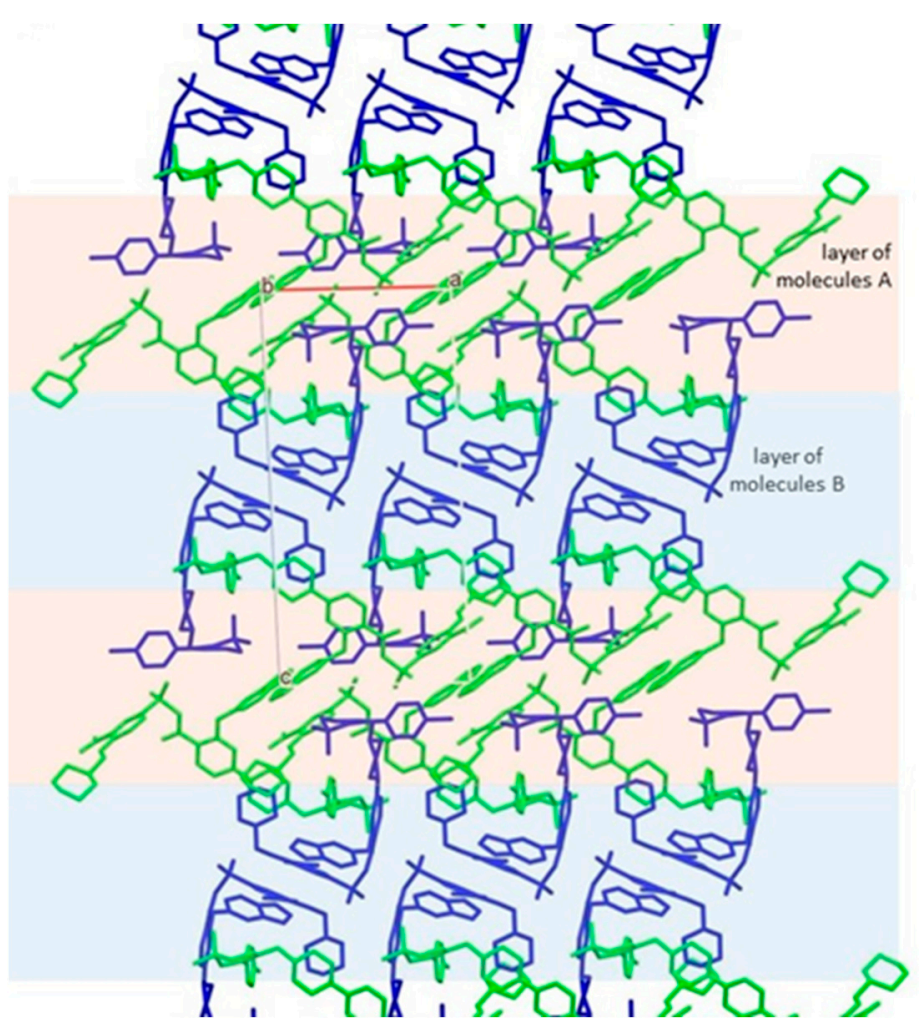

Figure 10. Packing of layers of molecules of A (green) and B (blue).

- Structural comparison between conformations of $\mathrm{VEN} \cdot \mathrm{H}_{2} \mathrm{O}$ and protein:venetoclax complexes

The crystal structure of $\mathbf{V E N} \cdot \mathbf{H}_{\mathbf{2}} \mathbf{O}$ possesses two crystallographically independent venetoclax molecules with distinctly different conformations. A variety of conformations are possible due to the composition of the molecule containing several rings connected primarily in para positions by flexible linkers. Free rotation along the $\mathrm{Ar}-\mathrm{NH}-\mathrm{CH}_{2}-\mathrm{R}$, $\mathrm{Ar}-\mathrm{CO}-\mathrm{NH}-\mathrm{SO}_{2}-\mathrm{Ar}, \mathrm{Ar}-\mathrm{O}-\mathrm{Ar}$, and $\mathrm{N}-\mathrm{CH}_{2}-\mathrm{R}$ linkers enables the molecules to adjust to different chemical spaces especially in protein binding sites. We decided to extend our research in order to compare conformations of molecules in $\mathbf{V E N} \cdot \mathbf{H}_{2} \mathbf{O}$ with the structures of venetoclax molecules from known crystal structures of protein:venetoclax complexes. VEN $\cdot \mathbf{H}_{\mathbf{2}} \mathbf{O}$ was compared with venetoclax molecules in complexes with a BCL-2 antagonist (two crystallographically independent molecules), G101V mutant (two crystallographically independent molecules), G101A mutant, and F104L mutant (two crystallographically independent molecules) [41] since hydrogen bonding and other non-covalent interactions, as well as packing effects, can have a marked influence on the conformation of the venetoclax molecule (Figure 11a). In all the venetoclax structures studied, the intramolecular hydrogen bond $\mathrm{N}-\mathrm{H} \cdots$ ONO between the amine group $\left(\mathrm{N} 3, \mathrm{~N} 10\right.$ in $\left.\mathbf{V E N} \cdot \mathbf{H}_{\mathbf{2}} \mathbf{O}\right)$ and the nitro group is present showing the robustness of this structural motif. On the other hand, the intramolecular hydrogen bond $\mathrm{N}-\mathrm{H} \cdots$ O between the amide group (N1, N8 in VEN $\left.\cdot \mathbf{H}_{2} \mathbf{O}\right)$ and the phenyl oxygen atom $\left(\mathrm{O} 7, \mathrm{O} 14\right.$ in $\left.\mathbf{V E N} \cdot \mathbf{H}_{\mathbf{2}} \mathbf{O}\right)$ can be observed only in VEN. $\mathrm{H}_{2} \mathrm{O}$ with a $\mathrm{N}(\mathrm{H})-\mathrm{C}(=\mathrm{O})-\mathrm{C}-\mathrm{C}(-\mathrm{O})$ dihedral angle of -5.32 and $-7.06^{\circ}$ (Figure $11 \mathrm{~b}$ ), respectively, while in all protein:venetoclax complexes, the amide $\mathrm{NH}$ group is directed away from the phenyl oxygen atom with dihedral angles in the range $140.7-155.4^{\circ}$ in five protein complexes (Figure 11c) and with a dihedral angle of 52.1 and $68.5^{\circ}$ in two protein complexes (Figure 11d). The $1 \mathrm{H}$-pyrrolopyridine unit in $\mathbf{V E N} \cdot \mathbf{H}_{\mathbf{2}} \mathbf{O}$ is involved in hydrogen bonding with adjacent molecules, while in all protein:venetoclax structures, it is involved in $\mathrm{N}-\mathrm{H} \cdots \mathrm{O}$ interactions with the carboxylate side arm of the aspartic acid unit of the protein chain. In most protein:venetoclax structures, the carbonyl oxygen atom of the amide unit 
interacts with the arginine side arm of the adjacent protein and/or water molecule, while sulfonyl oxygen atoms are mostly connected to water molecules and to the glycine $\mathrm{NH}$ amide group of the protein chain. Piperazine nitrogen atoms in $\mathbf{V E N} \cdot \mathbf{H}_{\mathbf{2}} \mathbf{O}$ are not involved in hydrogen bonding; however, in all protein:venetoclax complexes, one nitrogen atom interacts with a water molecule. Since venetoclax molecules in protein complexes are in a markedly different environment with respect to $\mathbf{V E N} \cdot \mathbf{H}_{\mathbf{2}} \mathbf{O}$, adopted conformations vary greatly. However, the $1 H$-pyrrolopyridine and nitrobenzene moieties are in close proximity, as is also observed in molecule B of VEN $\cdot \mathbf{H}_{\mathbf{2}} \mathbf{O}$. On the other hand, the chlorobenzene ring in both molecules of $\mathbf{V E N} \cdot \mathbf{H}_{\mathbf{2}} \mathbf{O}$ is directed in the opposite direction compared to in all of the protein complexes.

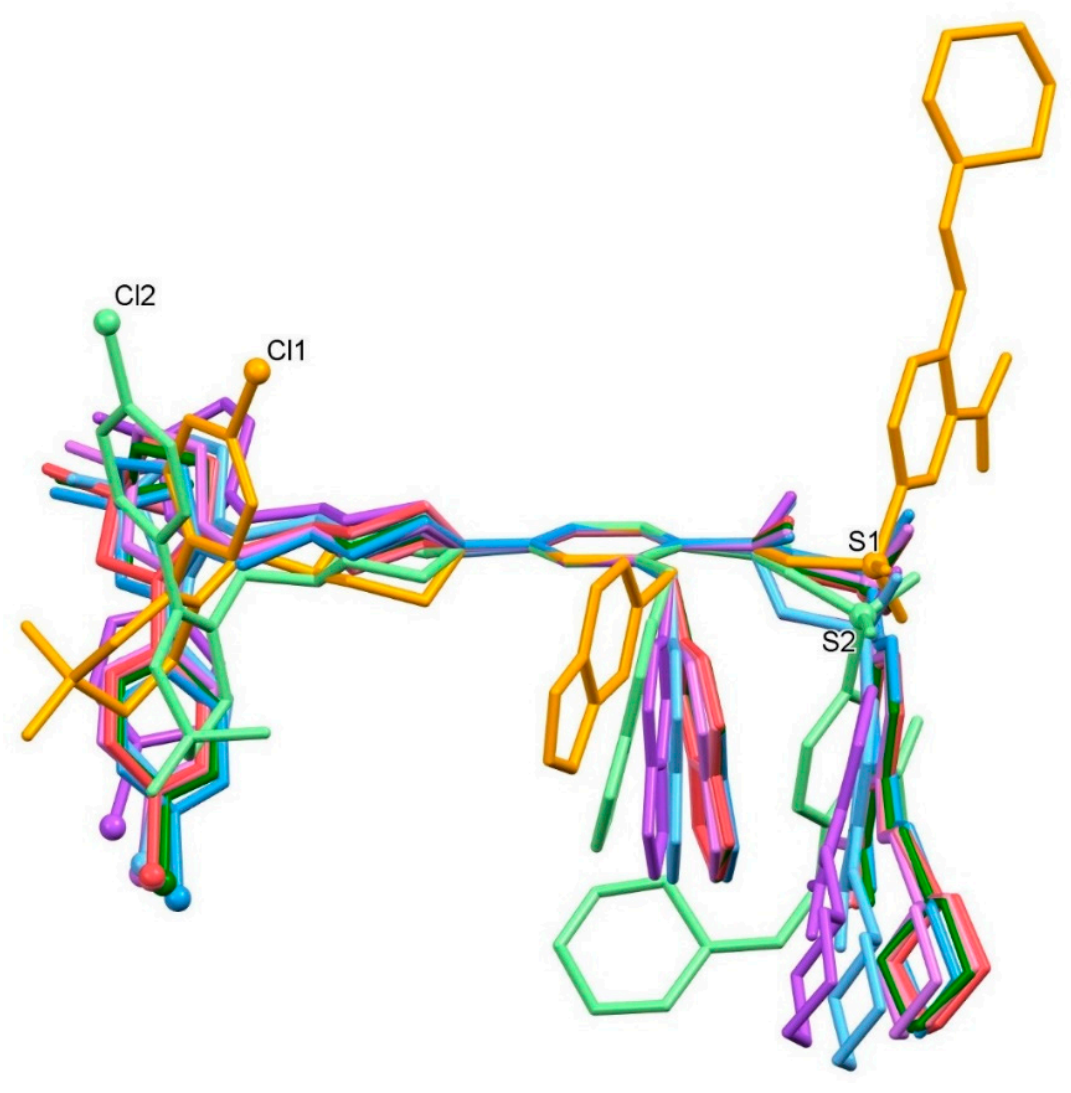

(a)

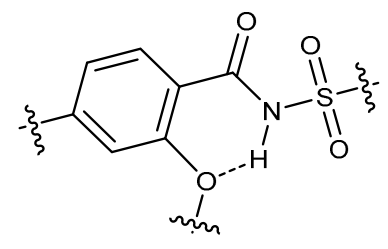

(b)<smiles>COc1cc(C)ccc1C(=O)NS(C)(=O)=O</smiles>

(c)<smiles>COc1cc(C(C)(C)C)ccc1C(=O)NS(C)(=O)=O</smiles>

(d)

Figure 11. (a) Superposition showing the difference in conformation of venetoclax molecules in $\mathbf{V E N} \cdot \mathrm{H}_{\mathbf{2}} \mathrm{O}(\mathrm{A}-\mathrm{orange}$, $\mathrm{B}$-light green) from this work and venetoclax molecules from the BCL-2:venetoclax complex (A-blue, B-light blue), BCL2 G101V:venetoclax complex (A-red, B-pink), BCL-2 G101A:venetoclax complex (green), and BCL-2 F104L:venetoclax complex (A-magenta, B-light magenta) from Birkinshaw and Czabotar [41]. For clarity, hydrogen atoms are omitted, and $\mathrm{Cl}$ and $\mathrm{S}$ atoms are drawn as small spheres. Differences in the orientation of the sulfonylamide moiety in $(\mathbf{b}) \mathbf{V E N} \cdot \mathrm{H}_{2} \mathrm{O}$ versus (c) most of the protein:venetoclax complexes and (d) molecules of B in BCL-2 and in BCL-2 G101A.

\section{Conclusions}

In this report, we present the first crystal structure of venetoclax, a B-cell lymphoma-2 selective inhibitor used for the treatment of chronic lymphocytic leukemia, small lymphocytic lymphoma, and acute myeloid leukemia. The X-ray single crystal structural analysis revealed the formation of venetoclax hydrate $\left(\mathbf{V E N} \cdot \mathbf{H}_{2} \mathrm{O}\right)$ crystalizing in triclinic space group $P-1$ with two crystallographically independent molecules of venetoclax (A and B) and two molecules of interstitial water in the asymmetric unit. Two intramolecular $\mathrm{N}-\mathrm{H} \cdots \mathrm{O}$ hydrogen bonds are present in both molecules, and a molecular overlay shows 
differences in their molecular conformations. Differences are also shown in respect to venetoclax molecules from known crystal structures of protein:venetoclax complexes with BCL-2 antagonist and BCL-2 mutants. In VEN $\cdot \mathbf{H}_{2} \mathbf{O}$, molecules of A form hydrogen bonded layers via a series of $\mathrm{N}-\mathrm{H} \cdots \mathrm{N}, \mathrm{C}-\mathrm{H} \cdots \mathrm{O}, \mathrm{ONO} \cdots \pi$, and $\pi \cdots \pi$ interactions, as well as molecules of $\mathrm{B}$ via $\mathrm{N}-\mathrm{H} \cdots \mathrm{N}, \mathrm{C}-\mathrm{H} \cdots \mathrm{O}, \mathrm{C}-\mathrm{H} \cdots \pi$, and $\pi \cdots \pi$ interactions. The supramolecular structure of VEN $\cdot \mathrm{H}_{2} \mathrm{O}$ is achieved through various $\mathrm{C}-\mathrm{H} \cdots \mathrm{O}, \mathrm{C}-\mathrm{H} \cdots \pi$, and $\mathrm{C}-\mathrm{Cl} \cdots \pi$ interactions between layers of molecules of $\mathrm{A}$ and layers of molecules of $\mathrm{B}$ as well as through the $\mathrm{O}-\mathrm{H} \cdots \mathrm{O}$ and $\mathrm{C}-\mathrm{H} \cdots \mathrm{O}$ interactions involving the hydrate molecules. The obtained crystals were additionally characterized with spectroscopic techniques, such as IR and Raman, as well as with thermal analysis.

Supplementary Materials: CCDC 2063224 contains the supplementary crystallographic data for this paper. These data can be obtained free of charge via www.ccdc.cam.ac.uk/data_request/cif or by emailing data_request@ccdc.cam.ac.uk or by contacting The Cambridge Crystallography Data Centre, 12 Union Road, Cambridge CB2 1EZ, UK; fax: +44 1223336033.

Author Contributions: Conceptualization, Z.Č.; methodology, N.Ž., Z.Č., and F.P.; validation, Z.Č., and F.P.; formal analysis, F.P. and Z.Č.; investigation, N.Ž., Z.C.., and F.P.; resources, Z.Č.; data curation, Z.Č. and F.P.; writing—original draft preparation, Z.Č. and F.P.; writing—review and editing, N.Ž., Z.Č., and F.P.; visualization, Z.Č. and F.P.; supervision, Z.Č.; project administration, Z.Č.; funding acquisition, Z.C. . All authors have read and agreed to the published version of the manuscript.

Funding: This research was funded by Lek Pharmaceuticals d.d. The APC was funded by Lek Pharmaceuticals d.d.

Data Availability Statement: All the data supporting the findings of this study are available within the article and supplementary materials.

Acknowledgments: Authors gratefully acknowledge D. Lipovec for technical assistance in crystallization experiments; $\mathrm{H}$. Cimerman for the acquisition of IR and Raman spectra as well as for the DCS and TGA measurements; and the EN-FIST Centre of Excellence, Ljubljana, Slovenia, for using the SuperNova diffractometer.

Conflicts of Interest: The authors declare no conflict of interest. The funders had no role in the design of the study; in the collection, analyses, or interpretation of data; in the writing of the manuscript, or in the decision to publish the results.

\section{References}

1. Lutz, R.J. Role of the BH3 (Bcl-2 homology 3) domain in the regulation of apoptosis and Bcl-2-related proteins. Biochem. Soc. Trans. 2000, 28, 51-56. [CrossRef] [PubMed]

2. Petch, A.; Al-Rubeai, M. The Bcl-2 family. In Cell Engineering: Apoptosis; Al-Rubeai, M., Fussenegger, M., Eds.; Springer Netherlands: Dordrecht, The Netherlands, 2004; Volume 4, pp. 25-47. ISBN 978-1-4020-2217-3. [CrossRef]

3. Ku, B.; Liang, C.; Jung, J.U.; Oh, B.H. Evidence that inhibition of BAX activation by BCL-2 involves its tight and preferential interaction with the BH3 domain of BAX. Cell Res. 2011, 21, 627-641. [CrossRef] [PubMed]

4. García-Sáez, A. The secrets of the Bcl-2 family. Cell Death Differ. 2012, 19, 1733-1740. [CrossRef] [PubMed]

5. Lopez, J.; Tait, S. Mitochondrial apoptosis: Killing cancer using the enemy within. Br. J. Cancer 2015, 112, 957-962. [CrossRef]

6. Delbridge, A.R.D.; Strasser, A. The BCL-2 protein family, BH3-mimetics and cancer therapy. Cell Death Differ. 2015, 22, 1071-1080. [CrossRef]

7. Dai, H.; Meng, X.W.; Kaufmann, S.H. Mitochondrial apoptosis and BH3 mimetics. F1000Research 2016, 5, 2804. [CrossRef] [PubMed]

8. Mandal, T.; Shin, S.; Aluvila, S.; Chen, H.C.; Grieve, C.; Choe, J.Y.; Cheng, E.H.; Hustedt, E.J.; Oh, K.J. Assembly of Bak homodimers into higher order homooligomers in the mitochondrial apoptotic pore. Sci. Rep. 2016, 6, 30763. [CrossRef]

9. Delbridge, A.R.D.; Grabow, S.; Strasser, A.; Vaux, D.L. Thirty years of BCL-2: Translating cell death discoveries into novel cancer therapies. Nat. Rev. Cancer 2016, 16, 99-109. [CrossRef]

10. Adams, J.M.; Cory, S. The BCL-2 arbiters of apoptosis and their growing role as cancer targets. Cell Death Differ. 2018, 25, 27-36. [CrossRef]

11. Kalkavan, H.; Green, D.R. MOMP, cell suicide as a BCL-2 family business. Cell Death Differ. 2018, 25, 46-55. [CrossRef]

12. Montero, J.; Letai, A. Why do BCL-2 inhibitors work and where should we use them in the clinic? Cell Death Differ. 2018, 25, 56-64. [CrossRef] [PubMed] 
13. Kale, J.; Osterlund, E.J.; Andrews, D.W. BCL-2 family proteins: Changing partners in the dance towards death. Cell Death Differ. 2018, 25, 65-80. [CrossRef] [PubMed]

14. Campbell, K.J.; Tait, S.W.G. Targeting BCL-2 regulated apoptosis in cancer. Open Biol. 2018, 8, 180002. [CrossRef] [PubMed]

15. Ngoi, N.Y.L.; Choong, C.; Lee, J.; Bellot, G.; Wong, A.L.; Goh, B.C.; Pervaiz, S. Targeting mitochondrial apoptosis to overcome treatment resistance in cancer. Cancers 2020, 12, 574. [CrossRef] [PubMed]

16. Explore BCL-2. Available online: https://www.genentechoncology.com/pathways/cancer-tumor-targets/bcl-2.html (accessed on 1 January 2021).

17. Srivastava, R.K.; Sasaki, C.Y.; Hardwick, J.M.; Longo, D.L. Bcl-2-mediated drug resistance: Inhibition of apoptosis by blocking nuclear factor of activated T lymphocytes (Nfat)-induced FAS ligand transcription. J. Exp. Med. 1999, 190, 253-266. [CrossRef]

18. Reed, J.C. BCL-2: Prevention of apoptosis as a mechanism of drug resistance. Oncol. Clin. N. Am. 1995, 9, 451-473. [CrossRef]

19. Reed, J.C.; Miyashita, T.; Takayama, S.; Wang, H.-G.; Sato, T.; Krajewski, S.; Aimé-Sempé, C.; Bodrug, S.; Kitada, S.; Hanada, M. BCL-2 family proteins: Regulators of cell death involved in the pathogenesis of cancer and resistance to therapy. J. Cell. Biochem. 1996, 60, 23-32. [CrossRef]

20. Flemming, A. Reversing resistance. Nat. Rev. Drug. Discov. 2008, 7, 119. [CrossRef]

21. D'Aguanno, S.; Del Bufalo, D. Inhibition of anti-apoptotic Bcl-2 proteins in preclinical and clinical studies: Current overview in cancer. Cells 2020, 9, 1287. [CrossRef]

22. Lin, V.S.; Xu, Z.-F.; Huang, D.C.S.; Thijssen, R. BH3 mimetics for the treatment of B-cell malignancies-Insights and lessons from the clinic. Cancers 2020, 12, 3353. [CrossRef]

23. Liu, Q.; Wang, H.-G. Anti-cancer drug discovery and development. Commun. Integr. Biol. 2012, 5, 557-565. [CrossRef] [PubMed]

24. Mullard, A. Pioneering apoptosis-targeted cancer drug poised for FDA approval. Nat. Rev. Drug Discov. 2016, 15, 147-149. [CrossRef] [PubMed]

25. Adams, C.M.; Clark-Garvey, S.; Porcu, P.; Eischen, C.M. Targeting the Bcl-2 family in B cell lymphoma. Front. Oncol. 2019, 8, 636. [CrossRef] [PubMed]

26. Sillar, J.R.; Enjeti, A.K. Targeting apoptotic pathways in acute myeloid leukaemia. Cancers 2019, 11, 1660. [CrossRef]

27. Carneiro, B.A.; El-Deiry, W.S. Targeting apoptosis in cancer therapy. Nat. Rev. Clin. Oncol. 2020, 17, 395-417. [CrossRef]

28. Souers, A.J.; Leverson, J.D.; Boghaert, E.R.; Ackler, S.L.; Catron, N.D.; Chen, J.; Dayton, B.D.; Ding, H.; Enschede, S.H.; Fairbrother, W.J.; et al. ABT-199, a potent and selective BCL-2 inhibitor, achieves antitumor activity while sparing platelets. Nat. Med. 2013, 19, 202-208. [CrossRef]

29. Deeks, E.D. Venetoclax: First global approval. Drugs 2016, 76, 979-987. [CrossRef]

30. King, A.C.; Peterson, T.J.; Horvat, T.Z.; Rodriguez, M.; Tang, L.A. Venetoclax: A first-in-class oral BCL-2 Inhibitor for the management of lymphoid malignancies. Ann. Pharmacother. 2017, 51, 410-416. [CrossRef]

31. Žigart, N.; Časar, Z. A literature review of the patent publications on venetoclax-A selective Bcl-2 inhibitor: Discovering the therapeutic potential of a novel chemotherapeutic agent. Expert Opin. Ther. Pat. 2019, 29, 487-496. [CrossRef]

32. Korycka-Wolowiec, A.; Wolowiec, D.; Kubiak-Mlonka, A.; Robak, T. Venetoclax in the treatment of chronic lymphocytic leukemia. Expert Opin. Drug Metab. Toxicol. 2019, 15, 353-366. [CrossRef]

33. Blair, H.A. Venetoclax: A review in previously untreated chronic lymphocytic leukaemia. Drugs 2020, 80, 1973-1980. [CrossRef] [PubMed]

34. Guerra, V.A.; DiNardo, C.; Konopleva, M. Venetoclax-based therapies for acute myeloid leukemia. Best Pract. Res. Clin. Haematol. 2019, 32, 145-153. [CrossRef]

35. DiNardo, C.D.; Jonas, B.A.; Pullarkat, V.; Thirman, M.J.; Garcia, J.S.; Wei, A.H.; Konopleva, M.; Döhner, H.; Letai, A.; Fenaux, P.; et al. Azacitidine and venetoclax in previously untreated acute myeloid leukemia. N. Engl. J. Med. 2020, 383, 617-629. [CrossRef]

36. Venclexta FDA Approval History. Available online: https://www.drugs.com/history/venclexta.html (accessed on 7 February 2021).

37. FDA Grants Regular Approval to Venetoclax in Combination for Untreated Acute Myeloid Leukemia. Available online: https:/ / www.fda.gov/drugs/drug-approvals-and-databases/fda-grants-regular-approval-venetoclax-combinationuntreated-acute-myeloid-leukemia (accessed on 7 February 2021).

38. FDA Approves Venetoclax for CLL or SLL, with or Without $17 \mathrm{p}$ Deletion, After One Prior Therapy. Available online: https: / / www.fda.gov/drugs/resources-information-approved-drugs/fda-approves-venetoclax-cll-or-sll-or-without-17-pdeletion-after-one-prior-therapy (accessed on 7 February 2021).

39. FDA Approves New Drug for Chronic Lymphocytic Leukemia in Patients with a Specific Chromosomal Abnormality. Available online: https: / / www.fda.gov/news-events/press-announcements/fda-approves-new-drug-chronic-lymphocytic-leukemiapatients-specific-chromosomal-abnormality (accessed on 7 February 2021).

40. Clinical Trials Using Venetoclax. Available online: https://www.cancer.gov/about-cancer/treatment/clinical-trials/ intervention/Venetoclax (accessed on 7 February 2021).

41. Birkinshaw, R.W.; Gong, J.N.; Luo, C.S.; Lio, D.; White, C.A.; Anderson, M.A.; Blombery, P.; Lessene, G.; Majewski, I.J.; Thijssen, R.; et al. Structures of BCL-2 in complex with venetoclax reveal the molecular basis of resistance mutations. Nat. Commun. 2019, 10, 2385. [CrossRef]

42. Catron, N.D.; Chen, S.; Gong, Y.; Zhang, G.G. Salts and Crystalline Forms of an Apoptosis-Inducing Agent. International Patent Application WO12071336 A1, 31 May 2012. 
43. Potarine Juhasz, Z.; Struba, S.; Nemethne Racz, C.; Toth, Z.G.; Szilagyi, A.; Kerti-Ferenczi, R.; Molnar, S.J.; Pasztor Debreczeni, N.; Hajko, J. Solid State Forms of Venetoclax and Processes for Preparation of Venetoclax. International Patent Application WO17156398 A1, 14 September 2017.

44. Vadali, L.R.; Gottumukkala, N.; Sangvikar, Y.; Jayachandra, S.B.; Jaldu, R. Polymorphic Forms of Venetoclax. WO19135253 A1, 11 July 2019.

45. Datta, S.; Grant, D.J.W. Crystal Structures of Drugs: Advances in Determination, Prediction and Engineering. Nat. Rev. Drug Discov. 2004, 3, 42-57. [CrossRef] [PubMed]

46. Rychkov, D.A.; Arkhipov, S.G.; Boldyreva, E.V. Simple and efficient modifications of well known techniques for reliable growth of high-quality crystals of small bioorganic molecules. J. Appl. Cryst. 2014, 47, 1435-1442. [CrossRef]

47. Growing Crystals for X-ray Diffraction Analysis. Available online: https://www.jove.com/v/10216/growing-crystals-for-X-raydiffraction-analysis (accessed on 14 February 2021).

48. Brameld, K.A.; Kuhn, B.; Reuter, D.C.; Stahl, M. Small molecule conformational preferences derived from crystal structure data. A medicinal chemistry focused analysis. J. Chem. Inf. Model. 2008, 48, 1-24. [CrossRef]

49. Groom, C. Small Molecule Crystal Structures in Drug Discovery. In Multifaceted Roles of Crystallography in Modern Drug Discovery. NATO Science for Peace and Security Series A: Chemistry and Biology; Scapin, G., Patel, D., Arnold, E., Eds.; Springer: Dordrecht, The Netherlands, 2015; pp. 107-114. [CrossRef]

50. Liebeschuetz, J.; Hennemann, J.; Olsson, T.; Groom, C.R. The good, the bad and the twisted: A survey of ligand geometry in protein crystal structures. J. Comput. Aided. Mol. Des. 2012, 26, 169-183. [CrossRef]

51. Zheng, Y.; Tice, C.M.; Singh, S.B. Conformational control in structure-based drug design. Bioorg. Med. Chem. Lett. 2017, 27, 2825-2837. [CrossRef]

52. Friedrich, N.-O.; Simsir, M.; Kirchmair, J. How diverse are the protein-bound conformations of small-molecule drugs and cofactors? Front. Chem. 2018, 6, 68. [CrossRef] [PubMed]

53. Jarvis, A.; Ouvry, G. Essential ingredients for rational drug design. Bioorg. Med. Chem. Lett. 2019, 29, 126674. [CrossRef] [PubMed]

54. Taylor, R.; Wood, P.A. A million crystal structures: The whole is greater than the sum of its parts. Chem. Rev. 2019, 119, 9427-9477. [CrossRef] [PubMed]

55. Agilent Technologies Ltd. CrysAlisPro, Version 1.171.36.28; Agilent Technologies: Yarnton, UK, 2013; Available online: https: / / www.agilent.com/cs/library/usermanuals/Public/CrysAlis_Pro_User_Manual.pdf (accessed on 7 February 2021).

56. Sheldrick, G.M. SHELXT_-Integrated space-group and crystal-structure determination. Acta Crystallogr. 2015, A71, 3-8. [CrossRef] [PubMed]

57. Sheldrick, G.M. Crystal structure refinement with SHELXL. Acta Crystallogr. 2015, C71, 3-8. [CrossRef]

58. Dolomanov, O.V.; Bourhis, L.J.; Gildea, R.J.; Howard, J.A.K.; Puschmann, H. OLEX2: A complete structure solution, refinement and analysis program. J. Appl. Crystallogr. 2009, 42, 339-341. [CrossRef]

59. Žigart, N.; Črnugelj, M.; Ilaš, J.; Časar, Z. On the stability and degradation pathways of venetoclax under stress conditions. Pharmaceutics 2020, 12, 639. [CrossRef]

60. Žigart, N.; Časar, Z. Development of a stability-indicating analytical method for determination of venetoclax using AQbD principles. ACS Omega 2020, 5, 17726-17742. [CrossRef] [PubMed]

61. Bernstein, J.; Davis, R.E.; Shimoni, L.; Chang, N.L. Patterns in hydrogen bonding: Functionality and graph set analysis in crystals. Angew. Chem. Int. Ed. 1995, 34, 1555-1573. [CrossRef] 